do Caldeirão, Tomar) relatório de estágio realizado na Faculdade de Ciências, Lisboa (1986).

(17) Light, Truman S.; Cappuccino, Carleton C., J. Chem. Educ. 52(4), 247-250 (1975).

(18) Komljenović, Josipa; Krka, Silvestar; Radić, Njegomir, Anal. Chem., 58(13), 2893-2895 (1986).

(19) Cammann, Karl, Working With Ion-Selective Electrodes, Berlin-Heidelberg, Springer-Verlag (1979).

(20) Brand, M. J.; Rechnitz, G. A., Anal. Chem., 42(11), 1172-1177 (1970).

(21) Zilhão, João Carlos Teiga, $O$ Solutrense da Estremadura Portuguesa, trabalho de sintese para provas de aptidão pedagógica e capacidade científica, Faculdade de Letras, Lisboa (1987).
TABELA I

O teor em flúor nos ossos da gruta do Caldeirão, segundo a camado estratigráfica (a incerteza refere-se a uma probabilidade de 95\%).

\begin{tabular}{cll}
\hline $\begin{array}{c}\text { Camada } \\
\text { estratigráfica }\end{array}$ & \multicolumn{1}{c}{$\begin{array}{c}\text { Datação C-14 } \\
\text { (anos B.P.) (21) }\end{array}$} & \multicolumn{1}{c}{ Teor em flúor (\%) } \\
\hline $\mathrm{E}_{\mathrm{a}}$ & - & $0,016 \pm 0,003-0,029 \pm 0,003$ \\
$\mathrm{E}_{\mathrm{b}}$ & $10700 \pm 380 ; 14450 \pm 890$ & $0,027 \pm 0,002-0,067 \pm 0,007$ \\
$\mathrm{~F}_{\mathrm{a}}$ & $15170 \pm 740$ & $0,082 \pm 0,005-0,304 \pm 0,052$ \\
\hline
\end{tabular}

Caro Leitor,

Estou particularmente feliz mas preocupado porque a partir de agora conto com um concorrente na produção humorística, se bem que, como o próprio admite, não seja (o meu concorrente) pessoa particularmente espirituosa.

Pede também o meu concorrente, "que os leitores enviem as suas piadas para o Director do boletim, que certamente lhes dará a merecida divulgação". É o que se chama uma subversão..., V.M.S. Gil (1) quer retirar os leitores-autores deste vosso fiel escrivinhador.

V.M.S. Gil lança um desafio, e Florêncio Vesúvio aceita a réplica e pede: ....queridos leitores mandem as piadas cá para o vosso Professor Florêncio Vesúvio que anda nisto do humor há mais tempo.

Além disso, eu Florêncio Vesúvio, ofereço um balde de plástico cheio de detergente Tipol à piada mais divertida que me fôr enviada... E agora sim vamos ao...

\section{O novo léxico científico}

Prometi aos nossos leitores voltar à lei, e como as promessas são para cumprir eis-nos de volta com a lei.

Lei de Dalton - (Em homenagem ao mais célebre irmão da ilustre família... Joe). Também enunciada como lei do Far-West, ainda em vigor em muitas regiðes do nosso planeta.

"O Gil esta piada não é assim tão fácil... era capaz duma assim?» Esta lei prima pela sua ausência e numa perspectiva da dialéctica hegeliana (li o livro por alturas do Maio de 68) corresponde à sua contradição.

... deixem-me interromper a lei, e falar nos modelos...
Não sei porquê?... mas desde cedo houve uma atracção dos Químicos e Físicos pelos modelos. Ainda bem que nenhum destes cientistas se candidatou a Presidente do seu País, porque decerto lhes aconteceria o mesmo que ao coiso... ao Hart. E o facto é que os ditos modelos são tão citados como... os... não é... está a perceber! No modelo de Bohr ainda hoje se fala... ah! Niels seu malandro... mas pronto voltemos à lei!

Lei de Beer - (Vá lá que eu vou explicar a piada. Há a lei de Beer, não é... mas Beer também é cerveja em Inglês... têm graça ò....). Mais conhecida pela lei seca, e segundo a qual era proibido a ingestão de cervejinhas provenientes do C.E.E. A propósito sabem que as associaçð̃es em paralelo, vão contra o princípio da Unicidade Sindical. E que uma reacção em cadeia pode degenerar num motim. E uma reacção de precipitação quase sempre se torna numa asneira... Ai! e o modelo de Bohr devia ser cá uma coisa... para ainda hoje se falar nele.

Lei dos Estados Correspondentes - (Quando os estados não se correspondem... estamos mal. Em vez de selos mandam ameixas...). Através desta lei foi possivel acertar uma franquia única para os selos postais, de tal modo que por exemplo nos USA o preço do selo para Portugal é o mesmo do que aquele pago por um qualquer cidadão em solo lusitano a escrever para os primos na Califórnia.

Estou farto de tanta lei pelo que dou por esgotado este tema. Até ao próximo número, E chega de leis... (H.C.C.) $)^{(2)}$

(2) Humanista e crítico científico 